Third International Engineering Systems Symposium

CESUN 2012, Delft University of Technology, 18-20 June 2012

\title{
Equity and the Ethics of Water Governance
}

\author{
Neelke Doorn ${ }^{1}$ \\ ${ }^{1}$ Delft University of Technology, Department of Technology, Policy and Management, \\ P.O. Box 5015, 2600 GA Delft, The Netherlands \\ N.Doorn@tudelft.nl
}

\begin{abstract}
Water is recognized to pose some very urgent questions in the near future. A significant number of people are deprived of clean drinking water and sanitation services, with an accordingly high percentage of people dying from water borne diseases. At the same time, an increasing percentage of the global population lives in areas that are at risk of flooding, partly exacerbated by climate change. In this paper, it is argued that ethics should be an integrated part of water governance in order to address these pressing issues. This paper consists of two parts. In the first part, some conceptual groundwork is done to clarify a number of persistent ambiguities and misunderstandings in the debate on water governance. In the second part, three distributive questions are outlined, concerning (1) the distribution of scarce resources, (2) the distribution of risks, and (3) the distribution of responsibilities. The paper is concluded with an outline for an ethics of water governance.
\end{abstract}

Keywords. water, access, allocation, equity, ethics, distributive justice, human rights, values, property regimes

\section{Introduction}

Water is essential for human life. However, due to its scarcity, the management of water is a topic of great concern. Inadequate management may lead to famines, food insecurity, ecological destruction, and resource-based conflicts, and eventually to human suffering and the loss of millions of human lives. Whereas some official organizations speak of a water crisis (World Bank, 2006; World Water Forum, 2009), others argue that there is sufficient water but that the water sector needs to be reformed to avoid a water crisis in the future (FAO/Kijne, 2003). Whether or not one uses the term "water crisis," the numbers are not encouraging. In 2010, more than one out of six people ( 0.7 billion people) lacked access to safe drinking water, and more than two out of six ( 2.6 billion people) lacked adequate sanitation. Almost 2 million people die every year from water borne diseases, most notably diarrhea (WHO, 2010). There are no official numbers on resource-based conflicts, but fact is that there are over 260 river basins shared by two or more countries, which may provide a source of (regional) instability or conflicts when strong institutions and agreements are missing. In the light of climate change, the impact of the global water crisis is expected to increase in the coming decades. 
Traditionally, water management has been seen as primarily a technical issue, belonging to the field of engineers and hydrologists. However, it is increasingly recognized that an adequate management of water requires that the institutional constraints and juridical context be taken into account. Both in academia and policy circles, the attention has therefore shifted from water management towards water governance, requiring the combined and coordinated effort of both technical (engineers, hydrologists) and non-technical experts (lawyers, economists, political and social scientists). Although different definitions of water governance exist, most of them refer to something like "the range of political, social, economic and administrative systems that are in place to develop and manage water resources, and the delivery of water services, at different levels of society" (Rogers and Hall, 2003: p. 18), mostly also including a reference to conflicting or diverse interests and cooperative action (cf. Bakker, 2003). With the shift from water management to water governance, the principle of equitable utilization has emerged in the literature as an important principle for allocation. ${ }^{1}$

Notwithstanding recurrent pleas to include issues of "equity" and "social justice" in the governance of water, ethicists or social philosophers have so far not or only barely been involved in the discussion. In this paper, I show that water governance prompts some urgent distributive issues. I argue that moral philosophers should become more involved in the discussions on water governance in order to develop an integrated account of water governance. The outline of this paper is as follows. After clarifying some issues concerning the nature of water and people's legal endowments in Section 2, Section 3 is dedicated to three urgent distributive issues that need to be addressed. In the concluding section, I provide a preliminary outline for an ethics of water governance.

\section{Classification of resources and people's legal endowments}

A recurrent theme in the discussion on water governance is the common-versuscommodity controversy. This controversy is often confused with the discussion whether or not people have a basic right to water. These are two separate questions, though, and they should be kept apart. Whereas water as a human right refers to people's legal endowments, the common-versus-commodity controversy is an issue of property regime, which is applicable to resources (Bakker, 2007). This section contains some conceptual background to clarify the debate.

\subsection{Typology of goods and property regimes}

The debate concerning the typology of goods mainly takes places in economics and public administration, where there is an ongoing discussion on the role of government

1 Cf. Convention on the Protection and Use of Transboundary Watercourses and International Lakes 1992 ("Helsinki Watercourses Convention") [art. 2]; United Nations Convention on the Law of the Non-Navigational Uses of International Watercourses ("UN Watercourses Convention 1997) [art 5]; ILA Berlin Rules on Water Resources 2004 [art 12]. 
in allocating resources. In these fields, goods are usually classified along two dimensions, viz. the subtraction criterion and the exclusion criterion. The subtraction criterion distinguishes private consumption goods from public consumption goods. In case of private consumption goods, each individual's consumption of the good leads to subtraction of the amount of that good available for others. Common or collective goods, to the contrary can be enjoyed "in common in the sense that each individual's consumption of such a good leads to no subtraction from any other individual's consumption of that good" (Samuelson, 1954: p. 387). The exclusion criterion indicates whether or not someone can be excluded form benefiting once the good is produced (Musgrave, 1959). Combining the two criteria yields a two-by-two matrix with four types of goods, as shown in Table 1 (Ostrom and Ostrom, 1977).

Table 1. Typology of goods (Source: Ostrom and Ostrom, 1977).

\begin{tabular}{|l|c|c|}
\hline & $\begin{array}{c}\text { One person's consumption } \\
\text { subtracts from total } \\
\text { available to others }\end{array}$ & $\begin{array}{c}\text { One person's consumption } \\
\text { does not subtract from total } \\
\text { available to others }\end{array}$ \\
\hline Exclusion is feasible & Private goods & Toll goods \\
\hline Exclusion is not feasible & Common-pool resources & Public goods \\
\hline
\end{tabular}

Although classification along the subtraction criterion seems more or less given, property regimes and both technical and physical boundaries can affect the capacity to exclude potential beneficiaries (Cornes and Sandler, 1994). Hence, it is possible - to some extent at least - to shift between the rows in Table 1. Unlike public goods, common-pool resources face problems of overuse, because they are both subtractable and without exclusion mechanisms to limit individual people's use, which may ultimately lead to a tragedy of the commons (Hardin, 1968). In order to avoid or solve this problem, it has been proposed to implement exclusion mechanisms such that the common-pool resources turn into private goods. This "common-versus-commodity" controversy is now also topic of debate in water governance. Given the scarcity of water, water should be assigned a price in order to avoid overuse, some people argue (cf. the fourth of the Dublin principles stating that "Water is a public good and has a social and economic value in all its competing uses").

Empirical data suggest that some exclusion mechanism is indeed required for the sustainable management of scarce resources (cf. Agrawal and Goyal, 2001). However, exclusion has its price, be it not (only) in monetary terms. Treating water primarily as an economic good in an attempt to accommodate its value may result in affordability problems and paradoxically deprive people of access to water, even though the exclusion mechanism was implemented to reduce water scarcity. Alternative exclusion mechanisms are therefore required to allocate the scarce water resources and this is where the property rights come into play. Based on her work with Schlager (Schlager and Ostrom 1992; Ostrom and Schlager 1996) and the work of Aggarwal and Dupont (1999), Ostrom shows how differentiation between various forms of property rights affect the incentives that people face to manage scarce resources, where property is defined as "an enforceable authority to undertake particular actions in a specific domain" (Ostrom 2003: p. 249). By introducing socalled bundles of rights, Ostrom argues against the conventional (and simplistic) 
notions of full and exclusive property and ownership. She distinguishes between five types of rights, that constitute different bundles of rights associated with particular holder positions (Table 2).

Table 2. Bundles of rights associated with positions (Source: Ostrom and Schlager 1996).

\begin{tabular}{|c|c|c|c|c|c|}
\hline & $\begin{array}{c}\text { Full } \\
\text { owner }\end{array}$ & Proprietor & $\begin{array}{c}\text { Authorized } \\
\text { claimant }\end{array}$ & $\begin{array}{c}\text { Authorized } \\
\text { user }\end{array}$ & $\begin{array}{c}\text { Authorized } \\
\text { entrant }\end{array}$ \\
\hline Access & $\mathrm{X}$ & $\mathrm{X}$ & $\mathrm{X}$ & $\mathrm{X}$ & $\mathrm{X}$ \\
\hline Withdrawal & $\mathrm{X}$ & $\mathrm{X}$ & $\mathrm{X}$ & $\mathrm{X}$ & \\
\hline Management & $\mathrm{X}$ & $\mathrm{X}$ & $\mathrm{X}$ & & \\
\hline Exclusion & $\mathrm{X}$ & $\mathrm{X}$ & & & \\
\hline Alienation & $\mathrm{X}$ & & & & \\
\hline
\end{tabular}

Although space does not allow to go into detail about the particularities of the different property rights, the key message here is that, by varying between different bundles of rights, people may be encouraged to manage scarce resources effectively and still allow access to people who would otherwise be deprived of water.

In other words, although the type of good is conceptually distinct from the property rights that people can exercise on these goods, they are related in the sense that the different property regimes affect the possibilities of effective management and the question to what extent the good is prone to collective action problems.

\subsection{The human right to water}

Over the past decade, and partly as a response to the economic approach to water governance, the discussion on access to water is increasingly framed in terms of human rights. Although often presented as an antidote to a pure economic approach to water governance, the human right approach to water does not exclude an economic or commodity approach to water. In order to understand this, it is good to take a closer look at the history of how this right became recognized by the respective UN bodies.

Although the idea of water as a human right was mentioned in several international treaties before, the political recognition came in 2002, when an expert body of the UN Economic and Social Council (ECOSOC) assessed the implementation of the International Covenant on Economic, Social and Cultural Rights (ICESCR). The committee asserted that "[t]he human right to water entitles everyone to sufficient, safe, acceptable, physically accessible and affordable water for personal and domestic uses" (GC 15). ${ }^{2}$ The GC 15 prompted discussion on the nature of this right; the formulation was not clear on whether it was to be interpreted as a subordinate right necessary to achieve a primary human right (e.g., the right to food, health, or life) or as an independent human right (Bluemel, 2004). The committee was explicit, though,

2 ECOSOC Committee on Economic, Social and Cultural Rights, General Comment No. 15 (2002). 
in the obligations it imposed on States. A more political recognition of the human right to water came when, based on the Millennium Development goals, the concept of water as a human right was adopted by the UN's General Assembly. ${ }^{3}$ This decision was later confirmed by the Human Rights Council, which recognized that "the human right to water and sanitation are a part of the right to an adequate standard of living and inextricably related to the right to the highest attainable standard of physical and mental health, as well as the right to life and human dignity."4

Irrespective of the (in)dependency of the human right to water to other human rights, the ECOSOC Committee identified four key elements to provide normative content to this particular right to water. ${ }^{5}$ First, water should be available in sufficient quantity for personal and domestic use. Second, water required for each personal or domestic use should be safe. Third, water and water facilities and services have to be accessible to everyone without discrimination. This element is further specified in terms of (i) physical accessibility (distance from each household, educational institution and workplace); (ii) economic accessibility (affordability); and (iii) non-discrimination (accessibility to all). Fourth, information concerning water issues should be accessible. It is debatable whether these criteria are not equally applicable to, for example, the human right to food or whether the normative content cannot be derived from the human right to food. However, it should be clear that the way this human right is formulated does not exclude privatization of the water sector. It should suffice that people have access to water, by whomever this is provided.

One important point of criticism against the idea of water as a human right is that it lacks enforcement mechanisms and arrangements concerning water use (Grafton, 2000). Equity and sustainability, for example, would seem to require specific midlevel principles concerning "minimum water rights" and "maximum water use" (Hoekstra and Chapagain, 2008). There are examples where the introduction of a water right has increased water use by already well provided people at the expense of downstream users, simply because people want to exercise their right (Merrey, 2008). Hence, implementing water rights is not trivial and does not automatically lead to an improved situation for the people who are deprived of water.

\section{Distributive questions in water governance}

In this section, I discuss some distributive issues or questions that should be included in an integrated account of water governance. Space does not allow to describe all aspects that are relevant for an ethics of water governance in full detail, so I will limit myself to three important points.

3 General Assembly Resolution 64/292 of July 28, 2010.

4 Human Rights Council Resolution 15/9 of September 30, 2010.

5 ECOSOC (2002), paragraph 12. 


\subsection{Distribution of a scarce resource}

Water is both a source of risks and a scarce resource. Most of the literature on water governance focuses on the scarcity of water, operationalized in the notion of access to water. One of the complicating issues of water governance is that access to water includes the need for an adequate infrastructure for delivery and sanitation services. Discussing access to water solely in terms of available quantities misses (a) the fact that people have to travel unequal distances to collect their water, (b) the importance of water quality, and (c) the issue of infrastructure maintenance. Concerning the first point, in most developing countries, an extensive range of people is deprived of adequate access, most notably women, people with disabilities, children, refugees, prisoners, and nomadic communities (Langford, 2005).

Concerning water quality, current discussions on water governance seem too onesidedly focused on water supply, overlooking sanitation and wastewater management. The latter are equally important for human health and they should therefore be taken into account when talking about water governance. This holds even more in situations where the use of water leads to pollution of traditional water sources, for example due to agricultural run-off or industrial waste. As for the issue of maintenance of water infrastructure, insufficient funding may aggravate water shortage problems. It also prompts distributive questions concerning responsibilities, which I will discuss in Section 3.3.

\subsection{Distribution of risks}

Most discussions in water governance focus on water scarcity. However, the risk of flooding is, in some areas at least, equally or even more urgent. Especially in places where the local hydrological circumstances are affected by large infrastructural projects (such as hydro-power plants), both the risk of flooding and potential water scarcity may be present and solutions to the one problem may exacerbate the other problem. Where water scarcity prompts distributive questions concerning resources, flood risks prompt distributive questions concerning "safety": where to implement flood risk measures, what level of safety is required, is it acceptable that people living in the one area have a higher level of safety compared to people living in another area?

In the philosophy of risks, several criteria have been developed for assessing the acceptability of risks (Hansson, 2003). These considerations should also be taken into account in the context of flood risk mitigation. For flood risks, three criteria are especially important. The first concerns the distribution of risks and benefits. When implementing measures to reduce existing risks, it is important to take into account the degree to which risks and benefits are distributed. It is, for example, not fair if the same people always have to carry the risks whereas others gain benefits. The second concerns the question to what extent people have consented to the risk. If people have freely chosen to live in particular flood-prone areas, they can be considered to have consented to a lower level of safety. The word "freely" is crucial, though. If people 
have no other place to live, the choice for this flood-prone area cannot be considered to be done with full consent. This brings us to the third point, viz. the question whether or not people exposed to a particular risk have alternatives at their disposal. To illustrate this, consider the following two hypothetical situations. In the first situation, a group of farmers live in a polder that is vulnerable to flooding but which is also very fertile, especially for the type of crops these farmers are growing. There is no land nearby with similar favourable characteristics. Now compare this situation with a typical commuter town in a similar polder. Most residents work in the city 50 $\mathrm{km}$ away. They do not like to live in the city and prefer to live in the countryside. However, they are indifferent as to which particular area. There is an area nearby with a significantly lower risk of flooding. In the first situation (farmers), the inhabitants do not really have an alternative place to live. In the second situation (commuters), the inhabitants have alternative places to live. Even if they do not want to live in the city, there is an alternative location nearby where they could live with a lower risk of flooding. If people still prefer to live in the polder with the high risk, it seems that they have voluntarily chosen to be vulnerable to this risk level. From the perspective of social justice, if may be defensible that the government provides different standards of safety against flooding in these two situations.

This simple example shows that the choice for particular safety measures and safety levels cannot be made on sheer numbers. Other considerations play a role when deciding on the acceptability of particular safety levels and, accordingly, on the distribution of risks.

\subsection{Distribution of responsibilities}

The last distributive question I would like to discuss is the distribution of responsibilities. In terms of responsibilities, water governance is very complex. In this paper, I briefly touch on three points that may often obscure the distribution of responsibilities in water governance. The order in which I discuss these points does not reflect any priority or importance.

First, water governance is often closely related to a particular infrastructure, which needs to be constructed, operated, and maintained. These tasks do not necessarily have to be done by one and the same actor. This prompts questions concerning the definition of different actors' responsibilities: Where does one person's responsibility stop and begins the other person's responsibility? The responsibility for maintenance, for example, may be unclear when large water infrastructures are built with a double purpose, such as hydro-power plants which are also intended as flood risk measures (Lejon et al., 2009).

Second, the distribution of responsibilities may become unclear when certain tasks are delegated, for example, in the implementation of water rights. With water services increasingly being privatized, it is important that the different actors' responsibilities are identified and that some regulatory system is put in place to guarantee compliance (Lundqvist, 2000; Meinzen-Dick, 2007). 
Third, water governance is a global issue. Only rarely is water flow confined within state boundaries. In most situations, rivers flow through several countries. Upstream activities in one country may affect water availability in downstream countries, which may pose a source of potential conflict. In international law, the principles of equitable and reasonable utilization and of diligent prevention of significant transboundary harm have been introduced to facilitate peaceful cooperation with respect to scarce water resources (Dellapenna, 2003). These global arrangements seem indispensable for coordinating water withdrawals with transboundary impact. However, at the institutional level, the subsidiarity principle requires addressing water issues at the lowest community level possible. As a result, the water sector has seen a significant change, with water users and other stakeholders gradually playing a much more active and constructive role; a trend which is widely supported by academics and field workers alike. There is a potential tension between the need for global arrangements and a meaningful mandate at the lower community levels. The question how to strike the balance between local and global arrangements and how to distribute the responsibilities (between states and between the different management levels) is one of the pressing challenges for water governance at this time (Hoekstra and Chapagain, 2008).

\section{Concluding remarks}

In the previous section, I derived three important distributive questions: distribution of scarce resources, distribution of risks, and distribution of responsibilities. I hope to have shown that these questions cannot be answered on the basis of efficiency criteria alone. Ethics should be an integral part of water governance. Although this terms "equity" and "reasonable utilization" are often mentioned, they are only weakly substantiated in the legal literature, whereas it is recognized that they play a vital role in building cooperative relations in water networks (Meinzen-Dick, 2007). Moreover, questions concerning risks and questions concerning different actors' responsibilities are often left aside or based on misleading dichotomies between privatization and commodification on the one hand, and water rights on the other. Herewith, I do not want to claim that we should adopt an economic approach to water, but I want to avoid muddled debates based on fuzzy conceptions.

My claim is that (applied) philosophers should become more actively involved in the water debate, in particular for clarifying and trying to answer the distributive questions that are characteristic for water governance.

How are we to proceed? For sure, philosophers do not have the answer to all questions, especially not if they lack practical knowledge of the issues at stake. Addressing real-world problems also requires empirical insight in these processes. I therefore argue for a multidisciplinary approach and to let philosophers join forces with disciplines like law, hydrology, policy science, and new institutional economics (see (Gupta and Lebel, 2010) for a similar plea). If the ethical aspects of water governance are to be adequately addressed, the philosophical skills should be complemented with profound knowledge of water, including partly technical 
(hydrological) knowledge, knowledge of the prevailing legal constraints, combined with insights from policy sciences and institutional economics. Debate should be conducted at various levels of generality and specificity, and so must a proper account of water ethics include an assessment at various levels of abstraction. At the most abstract level, basic moral concepts, such as equity, justice, and democracy, need to be developed assessed, which requires the involvement of both legal and political theorists, and philosophers. At the mid-level, principles of equity and efficacy need to be translated to actual water governance practice. This cannot be done without also paying attention to local socio-cultural and hydrological circumstances. Additionally, the legal context (international treaties, national water law, etc.) determines the room for maneuver and should therefore be taken into account as well. At the most concrete level, specific institutions and strategies need to be designed. At this level, the involvement of policy theorists and scholars from institutional economics may play a crucial role. By including these different perspectives, we may contribute to the articulation of detailed and useful moral principles of water governance.

\section{References}

Aggarwal, V.K., Dupont, C. (1999), Goods, games, and institutions. International Political Science Review, 20, pp. 393-409.

Agrawal, A., Goyal, S. (2001), Group size and collection action: Third party monitoring in common-pool resources. Comparitive Political Studies, 34, pp. 63-93.

Bakker, K.J. (2003), From public to private to ... mutual? - Restructuring water supply governance in England and Wales. Geoforum, 34, pp. 359-374.

Bakker, K.J. (2007), The "commons" versus the "commodity": Alter-globalization, antiprivatization and the human right to water in the global south. Antipode, 39, pp. 430-455.

Bluemel, E.B. (2004), The implications of formulating a human right to water. Ecology Law Quarterly, 31, pp. 957-1006.

Cornes, R., Sandler, T. (1994), Are public goods myths. Journal of Theoretical Politics, 6, pp. 369-385.

Dellapenna, J.W. (2003), The customary international law of transboundary fresh waters. In: M. Fitzmaurice, M. Szuniewicz (eds.), Exploitation of Natural Resources in the 21st Century, pp. 143-190. Kluwer Law International, The Hague.

FAO/Kijne, J.W. (2003), Unlocking the Water Potential of Agriculture. Food and Agriculture Organization, Rome.

Grafton, R.Q. (2000), Governance of the commons: A role for the state? Land Economics, 76, pp. 504-517.

Gupta, J., Lebel, L. (2010), Access and allocation in earth system governance: water and climate change compared. International Environmental Agreements-Politics Law and Economics, 10, pp. 377-395.

Hansson, S.O. (2003), Ethical criteria of risk acceptance. Erkenntnis, 59, pp. 291-309.

Hardin, G. (1968), The tragedy of the commons. Science, 162, pp. 1243-1248. 
Hoekstra, A.Y., Chapagain, A.K. (2008), Globalization of Water: Sharing the Planet's Freshwater Resources. Blackwell Publishing, Malden, MA/Oxford.

Langford, M. (2005), The United Nations concept of water as a human right: A new paradigm for old problems? International Journal of Water Resources Development, 21, pp. 273-282.

Lejon, A.G.C., Malm Renöfält, B., Nilsson, C. (2009), Conflicts Associated with Dam Removal in Sweden. Ecology and Society, 14, pp. 4.

Lundqvist, J. (2000), Rules and roles in water policy and management - Need for clarification of rights and obligations. Water International, 25, pp. 194-201.

Meinzen-Dick, R.S. (2007), Beyond panaceas in water institutions. PNAS, 104, pp. 1520015205.

Merrey, D.J. (2008), Is normative integrated water resources management implementable? Charting a practical course with lessons from Southern Africa. Physics and Chemistry of the Earth, 33, pp. 899-905.

Musgrave, R.A. (1959), The Theory of Public Finance. McGraw-Hill, New York.

Ostrom, E. (2003), How types of goods and property rights jointly affect collective action. Journal of Theoretical Politics, 15, pp. 239-270.

Ostrom, V., Ostrom, E. (1977), A theory for institutional analysis of common pool problems. In: G. Hardin, J. Baden (eds.), Managing the Commons, pp. 157-172. W.H. Freeman, San Francisco, CA.

Ostrom, E., Schlager, E. (1996), The formation of property rights. In: S. Hanna, C. Folke, K.-G. Mäler (eds.), Rights to Nature. Island Press, Washington, DC.

Rogers, P., Hall, A.W. (2003), Effective Water Governance, Global Water Partnership Technical Committee (TEC) Background Papers No. 7.

Samuelson, P.A. (1954), The pure theory of public expenditure. Review of Economics and Statistics, 36, pp. 387-389.

Schlager, E., Ostrom, E. (1992), Property-rights regimes and natural-resources: A conceptual analysis. Land Economics, 68, pp. 249-262.

WHO (2010), Progress on sanitation and drinking water. Update 2010. WHO, Geneva.

World Bank (2006), World Development Report 2006: Equity and Development. World Bank, Washington.

World Water Forum (2009), Global Water Framework. Outcomes of the 5th World Water Forum, Istanbul 2009. World Water Council, Marseilles. 